\title{
The sinkhole enigma in the Alpine Foreland, Southeast Germany: Evidence of impact-induced rock liquefaction processes
}

Research Article

\author{
Kord Ernstson ${ }^{1}$, Werner Mayer ${ }^{2}$, Andreas Neumair*2, Dirk Sudhaus ${ }^{3}$ \\ 1 Faculty of Philosophy I, University of Würzburg, \\ D-97074 Würzburg, Germany \\ 2 Institute for Interdisciplinary Studies, \\ D-82205 Gilching, Germany \\ 3 Institute of Geography, University of Augsburg, \\ D-86135 Augsburg, Germany
}

Received 15 July 2011 ; accepted 5 November 2011

\begin{abstract}
Sudden collapse of the Quaternary soil to form sinkholes on the order of meters and tens of meters has been a geologic phenomenon within living memory in a localized area north of Lake Chiemsee in Southeast Germany. Failing a satisfying explanation, a relation with an undefined glaciation process has always been proposed. Excavations and geophysical measurements at three newly affected sites show underground features such as prominent sandy-gravelly intrusions and extrusions typical of rock liquefaction processes well known to occur during strong earthquakes. Since strong earthquakes can reasonably be excluded to have affected the area under discussion, it has been suggested that the observed widespread liquefaction is related with the recently proposed Holocene Chiemgau meteorite impact event. Except for one earlier proposed but unassertive relation between impact and liquefaction, the obviously direct association of both processes in the Chiemgau area emphasizes that observed paleoliquefaction features need not necessarily have originated solely from paleoseismicity but can provide a recognizable regional impact signature.
\end{abstract}

Keywords: sinkholes (thunderholes) • liquefaction • seismicity • meteorite impact $•$ Kienberg-Southern Germany

(c) Versita sp. z o.o.

\section{Introduction}

Within living memory, the formation of so-called Thunderholes (in German: Donnerloch) has been a peculiar natural phenomenon constrained to an area of roughly $200 \mathrm{~km}^{2}$

*E-mail: andreas.neumair@arcor.de with a few isolated occurrences but a clear concentration near the town of Kienberg north of Lake Chiemsee in the Alpine Foreland in Southeast Germany (Figures 1, 4). Geologically, the Thunderholes are cave-ins that happen all of a sudden in a Quaternary sandy-gravelly and loamy underground. The sinkholes form on farmland, in forests (Figure 2), below construction sites (Figure 3), and a farmer has reported to have encountered a Thunderhole one morning in his cowshed, with the cow looking some- 


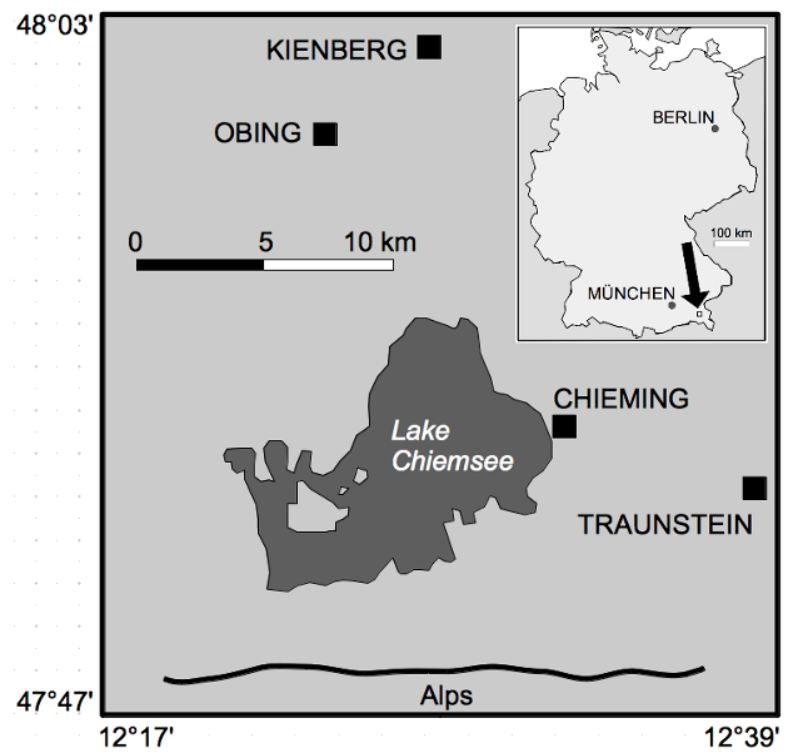

Figure 1. Location map for the Thunderhole phenomenon near Kienberg in the Alpine Foreland.

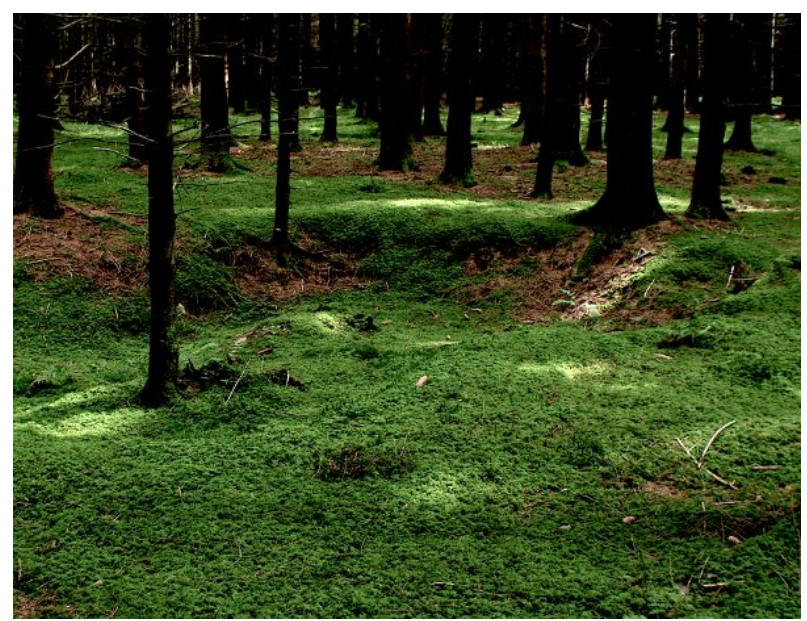

Figure 2. A typical $5 \mathrm{~m}$-diameter Thunderhole depression in a forest $5 \mathrm{~km}$ south of Kienberg (see Figure 4).

what irritated down at the bottom. Thunderholes that were found during excavation work for a large building had to be filled and stabilized by huge masses of cement, and one case has been reported where a Thunderhole was initially attributed to slipshod channel work by the contractor which led to a legal contention (H.-P. Matheisl, pers. comm.).

The surface diameter of the frequently circular holes ranges between about one meter and the order of ten meters, and farming vehicles are said to have completely caved in. Correspondingly, the depth of the holes may

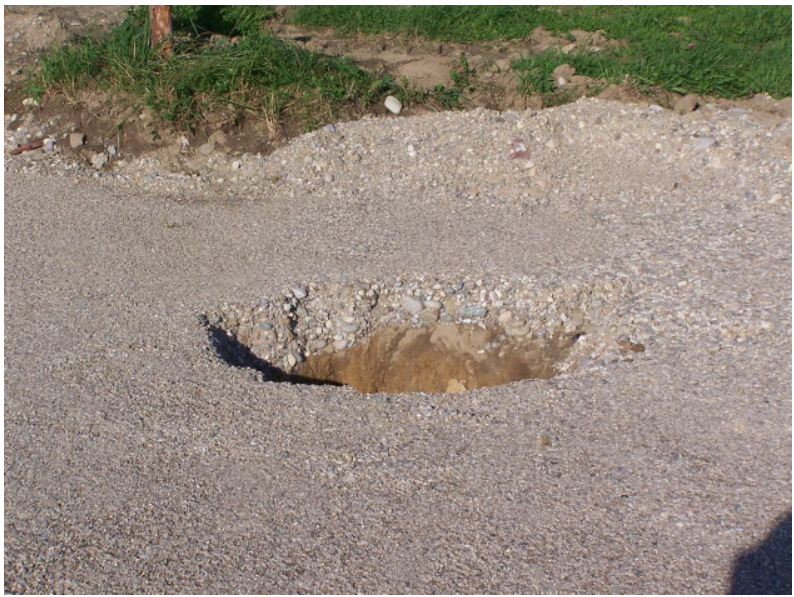

Figure 3. A $1 \mathrm{~m}$-diameter Thunderhole freshly collapsed during construction works.

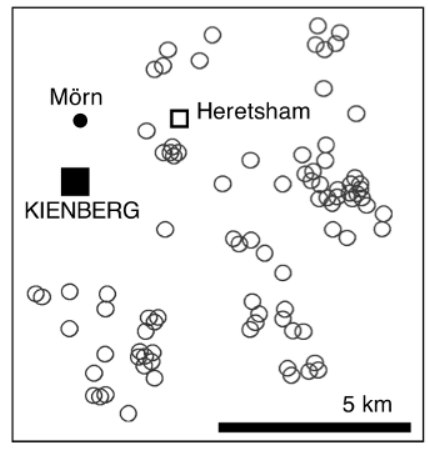

Figure 4. Distribution of 88 documented Thunderholes in the environs of the town of Kienberg. Actually, the total number of collapsed Thunderholes in this area is estimated to be four to five times as many. The excavations and geophysical measurements to be described have been performed at Heretsham and at the Mörn farmhouse.

reach to several meters. Abundant pear-shaped cavities can be observed. According to estimations of the local population, roughly one thousand Thunderholes may have formed in the past, and since about 20 years, newly developed holes are partly documented and described by the local authorities (Figure 4), hesitantly acknowledging the engineering geology issue of the phenomenon.

The cause of the Thunderhole formation has been a great enigma until today. This holds true even for geologists basically familiar with all kinds of sinkholes, which are not exactly rare in the widespread karst areas of Germany. However, with regard to the well-known stratigraphy of the region $[1,2]$ and the concentration on a small area otherwise not differing from the geologically identical Alpine 
Foreland over some 200 km, geologists' perplexity may be understandable. Thunderholes have sometimes been claimed as having an undefined relation with the ice age, given the glacially overprinted area (pers. comm. H. Urbauer, mayor of Kienberg). Formation as karst dissolution features has always been excluded.

The origin of the "Thunderhole" designation is unclear and has sometimes been ascribed to thunderstorms as the cause of the final collapse (local residents, pers. comm.). To avoid any confusion, we explicitly point to the fact that the term "Thunderhole" as used in this study is a customary name in the Kienberg environs. The name coincidence with, e.g., the North Carolina Thunderhole waterfalls; the Thunder Hole in Acadia National Park, Maine; the Thunder Hole offset sink from the Withlacoochee River in north central Florida and many more so-called Thunder Hole caves, does not infer any context of origin. The same holds true for the usage of the translated word "Donnerloch" in German for various karst sinkholes, subterranean streams, waterfall cascades and mining shafts in, e.g., Germany, Czechia and Alsace (France).

Here we report on a new approach to the Thunderhole phenomenon, aiming at unraveling the geologically exceptional situation. It is based on systematic deep excavation of two Thunderholes, on geophysical measurements, and on ideas taken from rock liquefaction processes during strong earthquakes [3-11] leading to a model that may explain all observed Thunderhole features. This model considers impact-induced seismic shaking as an alternative source for the Thunderhole development. While recent and fossil earthquake-induced soil liquefaction and rock liquefaction, with a focus on so-called sand injectites, is a common and fairly well understood process (e.g., [3, 1215]; and others), a possible underground liquefaction by terrestrial meteorite impact shock has so far been suggested in only one case in connection with the Upheaval Dome impact structure [16], although impact-induced seismic shaking has long been suspected to be an important surface modification process on small satellites and asteroids [17]. Beyond this focus on earthquake and impact liquefaction, we put the Thunderhole phenomenon in the global context of the manifold sinkhole formations, last but not least to emphasize its peculiarity as relevant for sinkhole origin in general.

\section{Material and methods}

\subsection{Study area}

The area under consideration is located near Lake Chiemsee in the Alpine Foreland in Bavaria, South-eastern Germany (Figure 1), which features a hilly landscape rich in

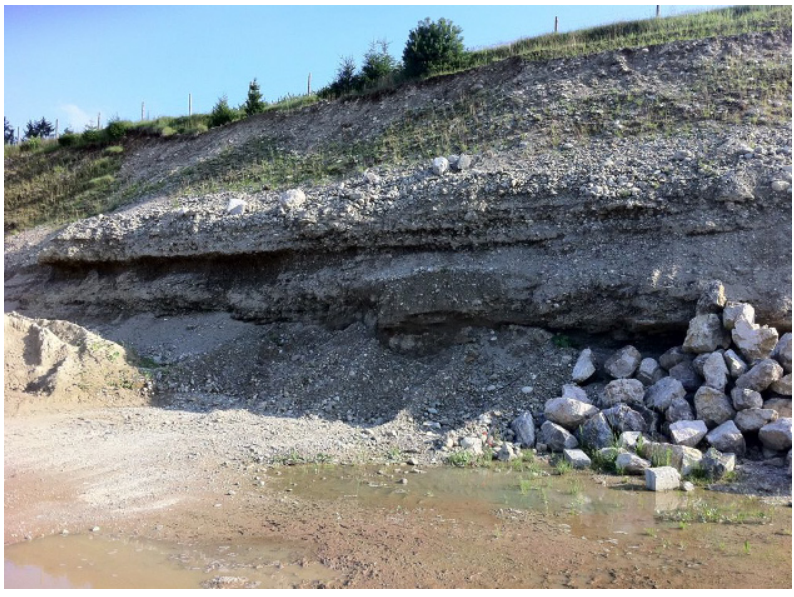

Figure 5. Gravel pit in the area of investigation showing intercalated cemented Nagelfluh layers. The thickness of the layers is between the order of centimeters and a few meters, and the cementation varies between weak and very strong, like concrete.

lakes and mires and which formed in the glacial Riss and Würm periods. The geological underground is composed of Pleistocene and Holocene moraine sediments and fluvial deposits. Pebbles, cobbles and boulders up to the size of $30 \mathrm{~cm}$ alternate with sands, clays and loamy material. The components represent Alpine material in the form of sedimentary rocks (c. $80 \%$, mostly limestones, dolostones) and crystalline rocks (c. $20 \%$, mostly metamorphic). Occasionally, meter-sized erratic blocks and larger blocks of strongly cemented conglomerates (Nagelfluh) are observed. In gravel pits, layers of Nagelfluh, which play a certain role in our study, frequently are seen as intercalated in the horizontally bedded soft sand and gravel layers (Figure 5). Locally, lacustrine clays, peat, loess and loamy soils contribute to the sedimentary spectrum. Below the roughly $50 \mathrm{~m}$ thick Quaternary sediments, Miocene, mostly composed of marls and clays, has been drilled. From a few very deep boreholes and reflection seismics, it is known that in the area under discussion, karstified rocks (Malmian limestones) are located as deep as $4000 \mathrm{~m}$ only.

\subsection{Excavations}

Two Thunderholes near Heretsham (Figure 4; Thunderhole \#1: coordinates 12²9'29.05"E, 48²'51.39"N; Thunderhole \#2: coordinates $12^{\circ} 29^{\prime} 42.7^{\prime \prime}, 48^{\circ} 3^{\prime} 0.3^{\prime \prime}$ ) that had been sealed by sand immediately after their collapse were excavated some months later. Excavations on areas up to $7 \times 7 \mathrm{~m}^{2}$ and several meters deep were accompanied by detailed geological examinations and recording of material and structures. 


\subsection{Geophysical measurements}

Before Thunderhole \#2 was excavated, a geoelectric survey in the form of electrical imaging was executed on a $20 \mathrm{~m}$ long profile across the sealed hole. In a pole-dipole (Half-Schlumberger) configuration the complex resistivity with $0^{\circ}$ and $90^{\circ}$ phase at $8.33 \mathrm{~Hz}$, corresponding to resistivity and induced polarization (IP) (e.g., [18]) was recorded. On the profile, the individual soundings with electrode layout perpendicular to profile strike were measured every $1 \mathrm{~m}$ at each point taking apparent resistivity and IP data for electrode spacings of $\mathrm{A}-\mathrm{MN}=1.5,2,2.5$, $3,4,5,6,7,8,10,12,15$ and $20 \mathrm{~m}$.

While in the Kienberg region under discussion, the Thunderhole collapses have always occurred as a matter of fact, a Thunderhole still under development has been observed for about two years. At the Mörn farmhouse (Figure 4; coordinates $\left.12^{\circ} 27^{\prime} 44.0^{\prime \prime} ; 48^{\circ} 03^{\prime} 5.7^{\prime \prime}\right)$ the residents found a $4.5 \mathrm{~m}$-diameter circular spot on their farmland where the soil showed a continuous subsidence of the order of $0.3 \mathrm{~m}$ within half a year providing an excellent opportunity to run a $40 \mathrm{~m}$ long profile of complex resistivity measurements across the center of the depression before the expected collapse.

As a result of the data sampling, apparent resistivity and apparent IP pseudosections were constructed, the latter by plotting the phase shift (in millirad) between current and voltage readings. The Lippmann Earth Resistivity Meter 4-Point light hp was used. Although computer programs enable modeling of pseudosections in the form of true resistivity, for 2D sections, such a processing seemed unreasonable because of the obvious a priori 3D underground structures. As a rough estimate, however, we performed 1D modeling of a few selected individual depth soundings.

Here, we point to geophysical measurements that previously have been performed to study soil liquefaction features in the New Madrid seismic zone $[19,20]$ and in Arkansas [21].

\section{Results}

\subsection{Excavations}

Thunderhole \#1 had a $0.8 \mathrm{~m}$ surface diameter and was $1.2 \mathrm{~m}$ deep. The powerful excavator that continuously paved the way for the geological recording by more handy tools had to stop at a depth of $3 \mathrm{~m}$ because of a strongly cemented gravel layer (the concrete-like socalled nagelfluh conglomerate) that the excavator was unable to penetrate. Although an insight into the deeper geological bedding, possibly bearing the "root" of the Thun-

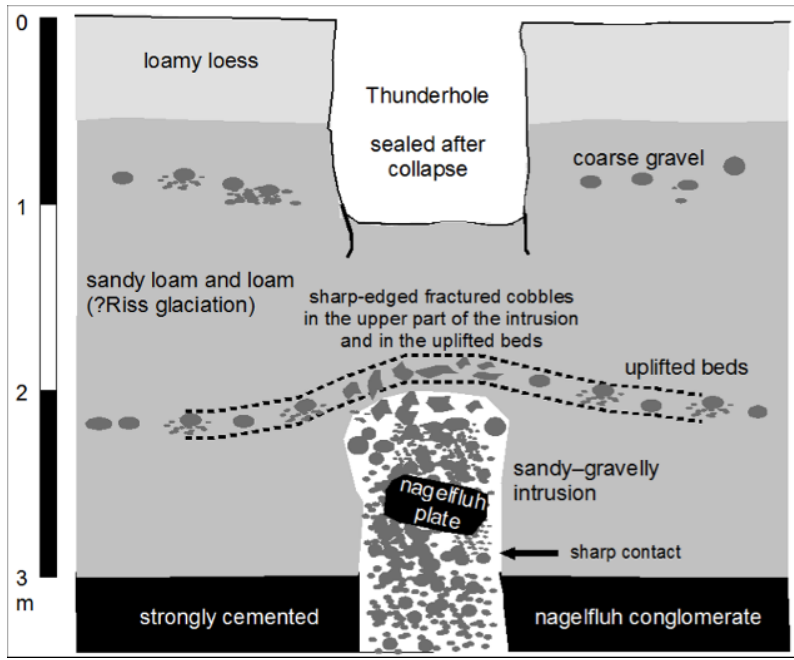

Figure 6. Schematic geological cross-section through the excavated Thunderhole \#1.

derhole, was hampered, the nagelfluh bed proved to be the basic clue to understanding what had happened. In a strongly simplified sketch, Figure 6 shows a vertical geologic section cutting through the Thunderhole. The section summarizes and generalizes the observations made in the whole excavation including, because of the central collapse, also more peripheral parts of the Thunderhole.

Below half a meter of loess a 2.5 m thick layer composed of possible Riss glaciation loam and sandy loam with intercalated coarse gravel was excavated before the excavator had to stop at the nagelfluh conglomerate (Figure 6). Here, the excavation revealed a prominent c. 0.7 m-diameter hole with a slightly elliptical crosssection punched into the nagelfluh bed concentric to the surficial Thunderhole collapse. The hole served as a vent for an intrusion of sandy-gravelly material obviously originating from deeper layers below the nagelfluh bed. Markedly uplifted fragmented nagelfluh plates sticking in the intrusion reveal transport from below (Figure 6). Obviously they must have been punched out from the nagelfluh layer. The intrusion from below must have been rather energetic and probably very rapid to have produced the sharp contact to the host rock and to have caused the significant uplift of the loamy and sandy-loamy beds to form a kind of arch (Figure 6). More evidence of a highly energetic process is given by lots of sharp-edged fractured cobbles contributing to the intrusion and the uplifted beds (Figure 7).

Thunderhole \#2, similar to \#1 with regard to depth and diameter, was excavated after a geophysical survey in the form of electrical imaging on a profile over the hole had been performed (see below). The excavation ran askance 


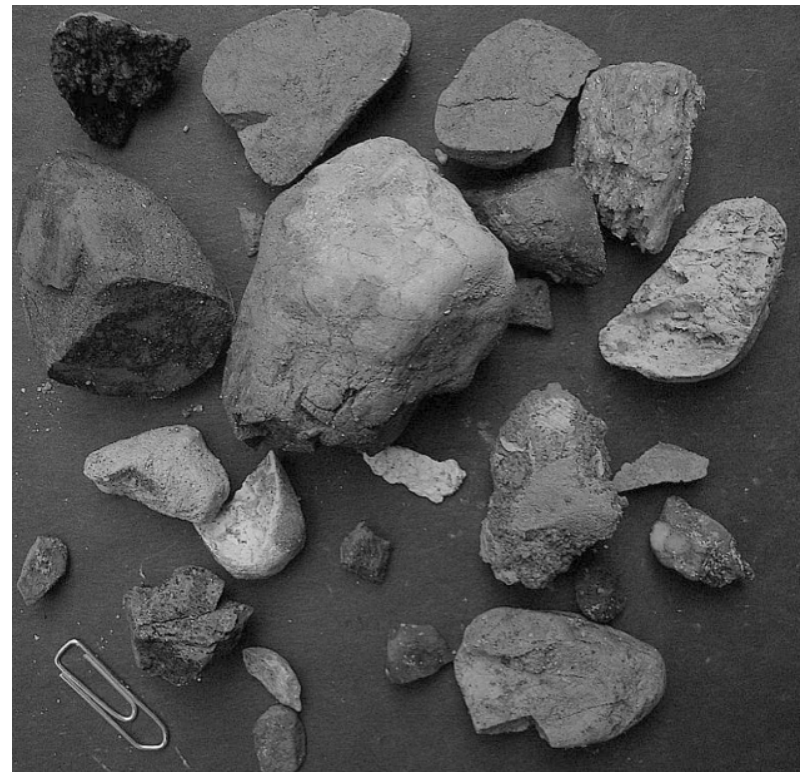

Figure 7. Sharp-edged fractured cobbles from the upper part of the intrusion and the uplifted beds.

and in the end measured a square of about $7 \times 7 \mathrm{~m}^{2}$. Slightly deeper than in Thunderhole \#1, the excavator found a nagelfluh bed at c. $3.5 \mathrm{~m}$ depth and again a prominent perforation below the surficial collapse. Compared with hole \#1, a much more complex scenario was encountered, implying several intrusions of sandy-gravelly material, open holes at depth (Figure 8) and impressively uplifted layers. Large nagelfluh blocks weighing up to several $100 \mathrm{~kg}$ and lifted up to one meter from the perforation were observed (Figure 9). As in hole \#1 the cobbles from the gravelly intrusions and the uplifted beds are to a large extent fractured, forming, together with the loamy material as matrix, real breccia zones (Figure 8).

Both excavations, obviously above the water table, showed normal rock and soil moisture; no liquid or gas escape was observed.

\subsection{Geophysical measurements}

Figure 10 shows the apparent resistivity pseudosection that in a first approximation provides a picture of the rock resistivity distribution in a vertical section along the profile. For the construction of the pseudosection the data at the $10 \mathrm{~m}$ profile station have been omitted because of a possible static shift of the apparent resistivities due to the sealing material of the Thunderhole.

At the ends of the profile the increasing apparent resistivity with depth has been modeled by a $\sim 3.5 \mathrm{~m}$ thick low-resistivity layer ( 60 Ohm·m) over a high-resistivity

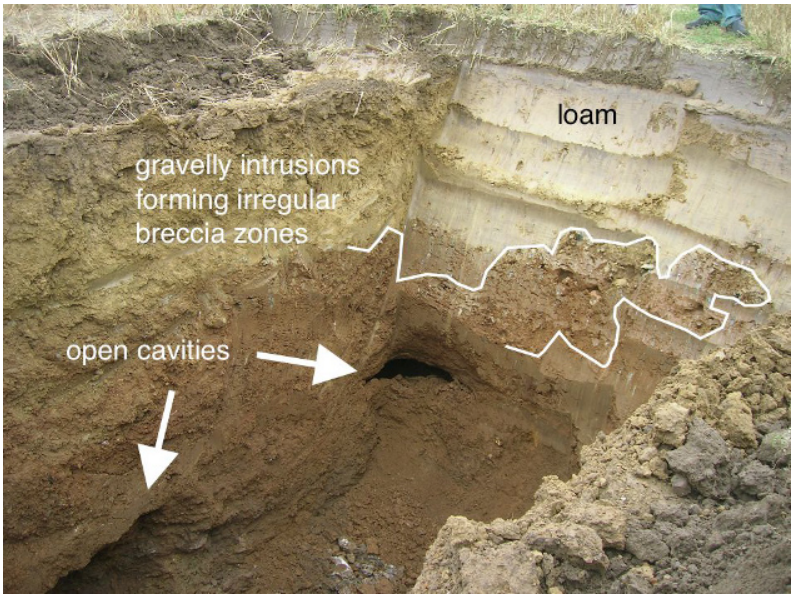

Figure 8. View into the approximately $3.5 \mathrm{~m}$ deep excavation pit \#2.

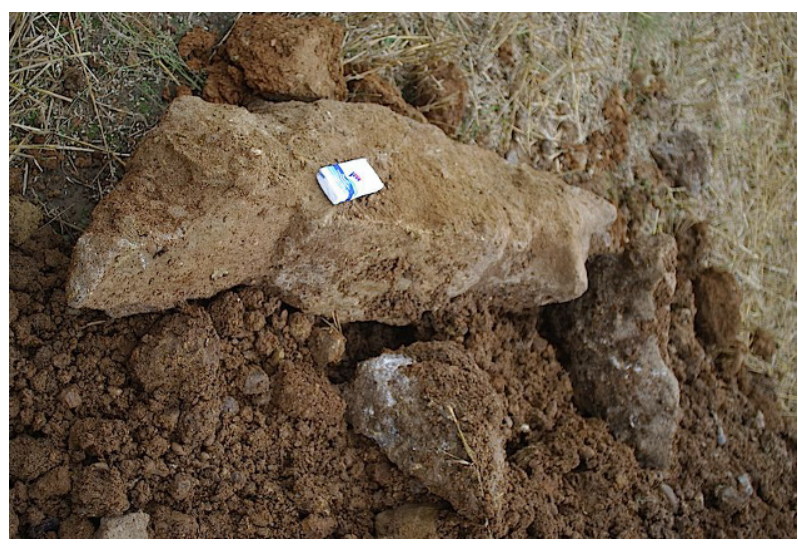

Figure 9. Nagelfluh blocks weighing up to several $100 \mathrm{~kg}$ and having been lifted up to $1 \mathrm{~m}$ from the perforation in Thunderhole \#2. Length of tissue bag, $11 \mathrm{~cm}$.

layer ( 1,000 Ohm.m) corresponding to loamy beds over Quaternary gravel and nagelfluh, as seen in the excavation outcrop. Roughly symmetrical to the position of the Thunderhole at $10 \mathrm{~m}$, the pseudosection shows a clear and pronounced uplift of the iso-ohms interpreted as originating from the intrusion of the high-resistivity gravel and nagelfluh material from below into the loamy layers of lower resistivity, as was later verified by the excavation. As can be seen in Figure 10, the doming of the layers occupies an extension even exceeding that exposed by the excavation along the geoelectric profile, and the locally raised iso-ohms at profile meters 3 and 16 may indicate further intrusions contributing to a doming as a whole. With regard to the peripheral resistivity "depressions" occurring symmetrical to the Thunderhole at about 4-6 m and 14-16 $\mathrm{m}$ it becomes evident that the superficial collapse of less than one meter diameter is only a small-scale 


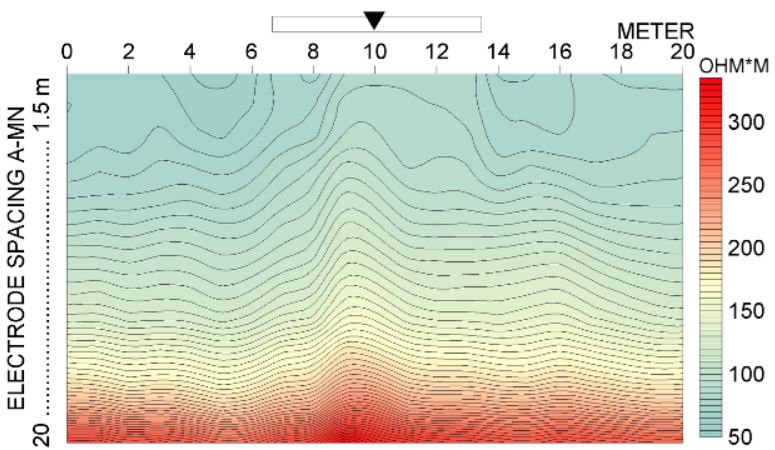

Figure 10. Apparent resistivity pseudosection across Thunderhole \#2 (at $10 \mathrm{~m}$ ), revealing a doming of the iso-ohms due to the intrusions of the high-resistivity material from below. The symmetric surficial iso-ohm depressions may reflect soil motions compensating for the mass deficit at depth. The rectangle indicates the extension of the excavation along the geoelectric profile.

snapshot in time of a much larger geologic scenario running in the subsurface. The iso-ohm "depressions" may reflect soil motions compensating for the mass deficiency at depth.

For comparison, Figure 11 shows the pseudosection for the apparent induced polarization, IP, expressed as phase shift (in millirad) between current and voltage. IP is a geoelectric petrophysical parameter that in sedimentary rocks is decisively affected by processes at the rock matrix - pore fluid interface. The clay content has significant influence on the IP magnitude, increasing with increasing clay content, but pure formations and pure clays in general show negligible IP. Also, a correlation of IP with resistivity is sometimes observed. Bearing this in mind, the IP pseudosection in Figure 11 reveals a very complex pattern completely different from what is known from fluvioglacial horizontal bedding normally exposed in gravel pits of the region (see Figure 5). Compared with the apparent resistivity pattern in Figure 10, the IP pattern may be termed ransacked, indicating that bedding has nearly completely been lost, although a rough general increase of IP with depth can be stated. We explain this distribution by the surficial loamy-clayey beds having low IP and, going deeper, by the chaotic intimate intermixing of these loamy-clayey beds with the sandy-gravelly material intruded from below resulting on the whole in enhanced IP. The most irregular IP pattern can be seen below the Thunderhole collapse, which is not surprising, but slightly vertically orientated structures around 2-3 m and $16 \mathrm{~m}$ profile length seem to correspond to the above-mentioned faint iso-ohm anomalies in Figure 10. Compared with the iso-ohm pattern in that figure, the far more pronounced IP pattern obviously is distinctly more sensitive to even faint

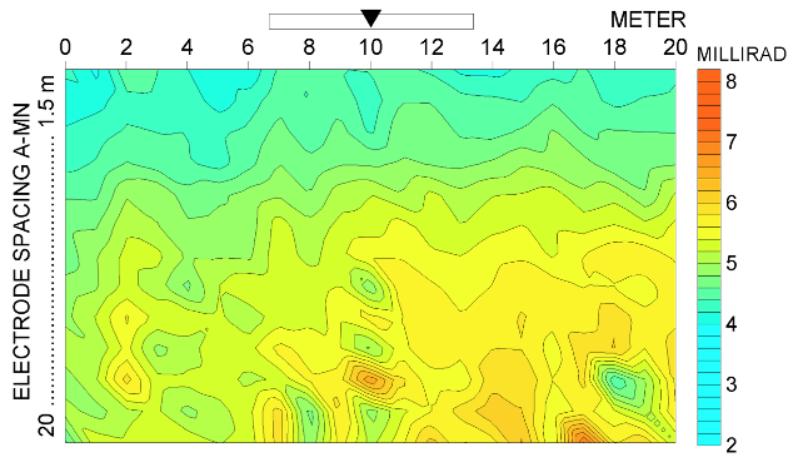

Figure 11. Apparent induced polarization (IP) pseudosection across Thunderhole \#2 (at $10 \mathrm{~m}$ ). The rectangle indicates the extension of the excavation along the geoelectric profile.

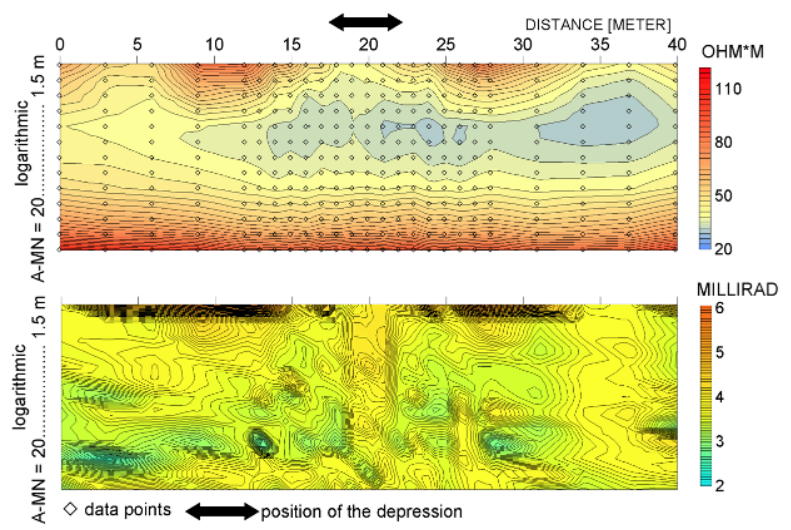

Figure 12. Complex resistivity measurements (pole-dipole configuration) on a diametrical profile across an active depression in the Thunderhole region at the Mörn farmhouse. Pseudosections of apparent resistivity, upper; and apparent induced polarization, lower.

changes of rock facies, an experience we have often made with complex resistivity soundings. This also is shown in the next example of Thunderhole geoelectrics.

Not really surprising, the resistivity and IP patterns (Figure 12) on the Mörn farmhouse profile, twice as long as that across Thunderhole \#2, prove to be very similar to the picture seen by the geoelectrics and excavation made over hole \#2.

As can be seen in Figure 11, the deformations as reflected by the iso-ohms (Figure 12, upper) span more or less symmetrically up to $20 \mathrm{~m}$ radial distance indicating a large rock volume involved in the underground Thunderhole forming process. Like at Thunderhole \#2, the IP patterns in Figure 12 are distinctly more expressive than the iso-ohms, establishing a $\sim 2 \mathrm{~m}$ wide channel or pipe of clear geometrical shape exactly below the center of the subsidence. Since the pipe practically reaches up to the surface, we suggest the intrusion from below was 
connected with an earlier blow-out possibly immediately during the original high-pressure event as discussed below. Such a burst may have happened also at profile meter 36-37, displaying another pipe, as seen in the IP. The more irregular pattern may be the result of the larger station spacing here. One more sharply portrayed pipe can be seen at profile meter 26 obviously reflecting a stuck intrusion from below.

\section{Discussion}

\subsection{Discussion of earthquake-induced Thun- derhole formation}

The observations as described have clear counterparts in geological processes and structures well known from strong earthquakes and related to soil or rock liquefaction $[3,9,11,22]$. Liquefaction occurs in watersaturated, unconsolidated, sand-rich sediments beneath a low-permeable clay-rich cap. Upon seismic shock, increased pore-water pressure can lead to a loss of adhesion of the sediment and breakdown of the framework, leading to complete fluidization in the form of a suspension initiating ground failure that includes explosive sand-blow craters, sand fissures, and intrusive and extrusive features with the low-permeable cap layers. Liquefaction is controlled, among many other factors, by sediment grain size, depth to the water table, and strength and duration of the seismic event. Onset of liquefaction depends on hypocentral distance and is assumed to be related to Richter magnitudes larger than roughly 5 (e.g. [11]). As early as in the strong 1783 Calabrian, Italy, earthquake, sand explosion craters have been recorded and later described by Charles Lyell (1830) in his famous Principles of Geology, Vol. 1. Probably the most extensive geologic documentation of this process that affected swaths of land over hundreds of kilometers happened during the 1811/1812 New Madrid, Missouri, devastating earthquake series $[23,24]$ and can be seen in many outcrops even today $[3,25,26]$. From the widespread literature on earthquake liquefaction and especially from the Stewart and Knox books, it is evident that the Thunderhole formation shows all aspects and features of an underground shock. Related liquefaction is permeable sandy-gravelly sediments below a practically impermeable cap of strongly cemented nagelfluh and overlying clay and loam. The intrusions of the liquefiable sand/gravel into and its extrusions through the non-liquefiable cap are shown and extensively described by Stewart and Knox [3, 25] (Figure 13); the extrusive model from Figure $13 \mathrm{C}$ seems to be a nearly perfect il-
A intrusive

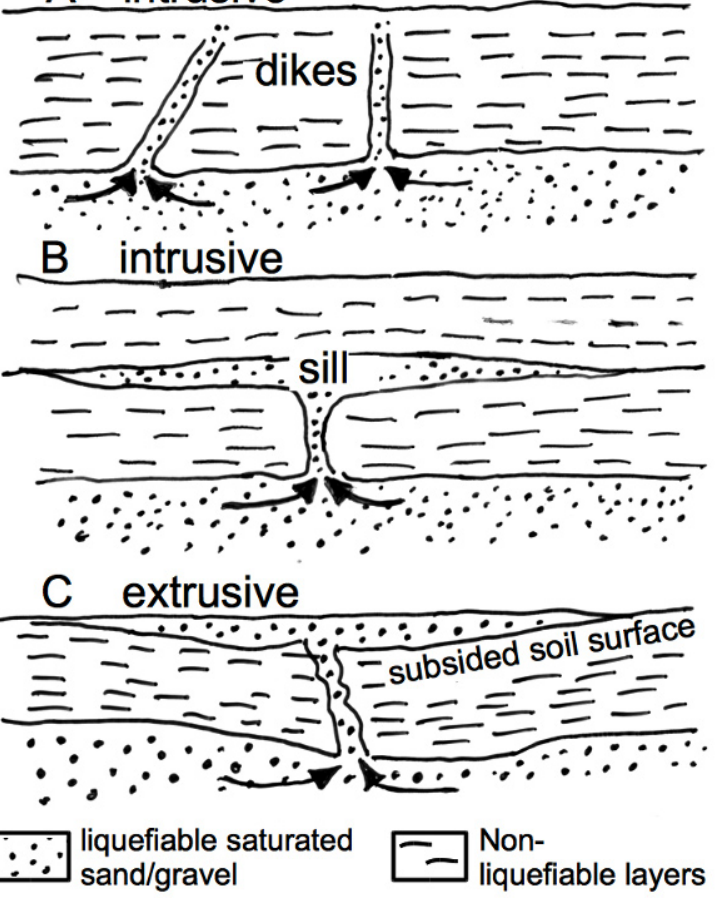

Figure 13. Sketches of soil liquefaction features originating from the $1811 / 1812$ New Madrid earthquake in Missouri, USA. Simplified and modified from [3].

lustration of what we are seeing in the geophysical picture of the developing Thunderhole in Figure 12.

The area around the town of Kienberg that displays a concentration of Thunderholes is free of earthquake epicenters. The distance between Kienberg and the nearest earthquake zone at the northern margin of the Alps (the Bad Reichenhall/Berchtesgaden region) is about 50 - $60 \mathrm{~km}$, and Mercalli intensities there seldom exceed the 3 - 4 stages [27] (e.g., Mercalli 4: felt outdoors by few people during the day). It is unlikely that these slight earthquakes could have caused prominent soil liquefaction at $50-60 \mathrm{~km}$ distance. This is underlined by intensities $>$ 5-6 (magnitude $>4.2$ ) reported for earthquake-induced liquefaction in Italy and $90 \%$ of the cases falling within $50 \mathrm{~km}$ of the epicenter [28]. During very strong earthquakes in, e.g., Northern Italy, liquefaction is also not expected to occur at some $150 \mathrm{~km}$ distance or more [11]. Moreover, in such a case it would be rather enigmatic as to why only the roughly $20 \mathrm{~km}$ sized area around Kienberg is affected by this far-away earthquake, although the same geology and topography is found in all points of the compass. Strong earthquake shaking released in prehistorical times and nearer to the Kienberg Thunderhole occurrences must be considered hypothetical. From the many limestone caves lining up in the nearby Northern Lime- 
stone Alps speleologists have never reported evidence for seismic shaking. The same holds true for the large number of gravel pits that, under current exploitation, have so far not featured respective attributes. Liquefaction as the cause of the Thunderhole formation therefore requests an event that happened much closer to the Kienberg region

\subsection{Discussion of other models of Thunder- hole formation}

Although liquefaction proves to be the most plausible explanation for the development and final collapse of the Thunderholes, we also will consider other possibilities, and here we have first to distinguish between the actual cave-ins (Figure 3) and depressions like in Figure 4 that in each case need not necessarily be true sinkholes. Where these depressions typically found in forests of the Kienberg region do not show any accumulation of excavated material, an anthropogenic origin (smelting or lime kiln purposes, as prospecting pits, bomb craters, housing estates) can largely be excluded.

In the case of obvious sinkholes observed by the local population we again have to distinguish between simple cave-ins and cave-ins that are connected with and follow some kind of extrusion processes. Pure cave-ins may be the result of anthropogenic activities or geologic processes. Sinkholes connected with mining shaft and gallery cave-ins are common but definitely can be excluded for the area under discussion. Sinkholes induced geologically by subsurface dissolution can likewise be excluded since rocks susceptible to karstification are not expected to occur in the Kienberg region in the upper $4000 \mathrm{~m}$ as already mentioned above. Even geologists puzzled as to why the soil collapses suddenly are disregarding karstification. [Sub]volcanic activity as a possible cause for the sinkhole formation is completely unknown. Strong water table oscillations having possibly caused underground washout and subsequent cave-ins can also be excluded for the Kienberg region. Internal erosion (piping) as a cause of sinkhole formation may also be discussed. Since sites of piping are virtually always found on slopes or, as an exception, related with the edge of a terrace [29], we can exclude piping in the case of the Kienberg sinkholes.

Natural gas in deeper layers $(>1,000 \mathrm{~m})$ of the Tertiary molasse sediments has been explored and produced. However, superficial gas blow-outs have never been observed or reported. Moreover we doubt that gas migration from those depths is able to build up the enormous near-surface gas pressure required for the observed perforation of the nagelfluh bank and the uplift of blocks weighing some $100 \mathrm{~kg}$.
Within the scope of anomalous sinkhole formation, larger energy must have been released also in the case of the Sirente craters. The Sirente crater field in Italy consists of about 30 depressions with a main rimmed 120 m-diameter crater. The origin of the craters is disputed and has been ascribed to meteorite impact [30], to mud volcanic processes [31] and to anthropogenic activities [32]. So far, no impact features like meteoritic material, geochemical signature or shock metamorphism have been identified [33], and in a more recent paper [34] the meteorite impact hypothesis has widely been disproved. Within the focus of this paper and the Thunderhole formation, the model of a mud volcano, implying mud-fountaining [31], is interesting, because liquefaction by seismic shock or sudden gas/water over-pressure plays a major role in the model, and large dislocated limestone blocks are suggested to be related with an extrusion process. So far, liquefaction and uplift of large blocks are common to both sites; the basic differences, however, are severe. The diameter of the Sirente main crater exceeds the Thunderhole diameters by one to two orders of magnitude. The rootless limestone blocks within the Sirente crater are ascribed to diapiric movement and obviously have originated from a limestone karstic substratum favoring the formation of piping sinkholes anyway. Moreover, the Sirente crater is located in a high seismicity area and close to an active fault both favorable for mud volcanism. Altogether, the proposed Sirente mud volcano fails to be a model for the Thunderhole formation.

\subsection{Discussion of meteorite impact-induced Thunderhole formation}

The similar effects of strong earthquake and meteorite impact wave propagation and ground deformation have established a connection between the Thunderhole formation and the recently proposed so-called Chiemgau impact event.

The Chiemgau strewn field [35-40] discovered in the early new millennium and dated to the Bronze Age/Celtic era comprises more than 80 mostly rimmed craters scattered in a region of about $60 \mathrm{~km}$ length and ca. $30 \mathrm{~km}$ width in the very South-East of Germany (Figure 14, Figure 1). The crater diameters range between a few meters and a few hundred meters. Geologically, the craters occur in Pleistocene moraine and fluvio-glacial sediments. The craters and surrounding areas so far investigated in more detail feature heavy deformations of the Quaternary cobbles and boulders, abundant fused rock material (impact melt rocks and various glasses), shock-metamorphic effects, and geophysical anomalies [36]. The impact is substantiated by the abundant occurrence of metallic, glass and carbon 


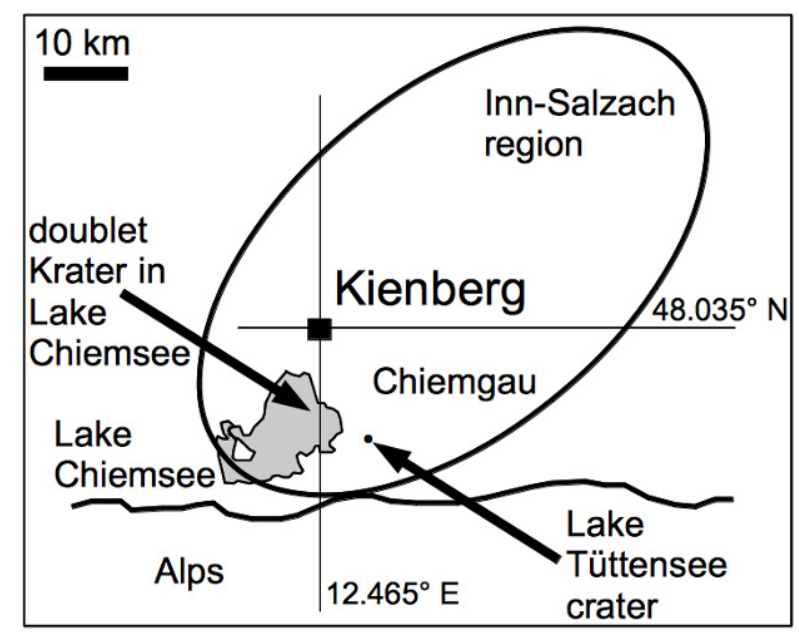

Figure 14. The Kienberg Thunderhole concentration in the elliptically shaped Chiemgau impact strewn field.

spherules, accretionary lapilli, and of strange matter in the form of iron silicides such as gupeiite and xifengite, and various carbides, e.g., moissanite $\mathrm{SiC}[36,39]$. Carbon spherules contain fullerene-like structures and nanodiamonds that point to an impact-related origin [41]. Such spherules were found embedded in the fusion crust of cobbles from a crater as well as a possible fallout in soils widespread over Europe [41, 42]. The hitherto established largest crater of the strewn field is Lake Tüttensee (location in Figure 14) exhibiting an $8 \mathrm{~m}$-height rim wall, a rimto-rim diameter of about $600 \mathrm{~m}$, a depth of roughly $30 \mathrm{~m}$ and an extensive ejecta blanket. Recent sonar soundings on Lake Chiemsee revealed the structure of a rimmed doublet crater sized about $900 \mathrm{~m} \times 400 \mathrm{~m}$ (location in Figure 14) [36]. Physical and archaeological dating confines the impact event to have happened most probably between 2,200 and 500 B.C. [37, 38]. The impactor is suggested to have been a roughly $1,000 \mathrm{~m}$ sized low-density disintegrated, loosely bound asteroid or a disintegrated comet in order to account for the extensive strewn field [36].

With regard to this extraordinary event and to the fact that the formation of larger meteorite craters by impact explosions produces similar effects like very strong earthquakes, the Thunderhole phenomenon in the Kienberg region directly located in the crater strewn field (Figure 14) has a plausible and easily understood explanation. Computer simulations using programs developed by, e.g., Collins et al. [43] suggest an equivalent Richter magnitude of 6.9 for the $600 \mathrm{~m}$ Lake Tüttensee crater impact (M.A. Rappenglück, pers. comm.). The proposed $900 \mathrm{~m} \times 400 \mathrm{~m}$ doublet impact crater in lake Chiemsee at a distance of no more than $10 \mathrm{~km}$ to the Kienberg area should have produced even much stronger seismic shaking, not to for- get additional input by the rest of the crater-forming projectiles in the strewn field, enhancing effects of interfering shock waves, and by high-intensity aboveground projectile explosions perhaps comparable to the 1908 Tunguska event [44]. Although liquefaction documented during underground explosions is characterized by higher threshold energy than that for liquefaction during earthquakes [11], the position of the Kienberg Thunderhole area more or less in the focus of the impact seismic shaking is strong evidence for the validity of our model. Correspondingly, the following sequence of events is suggested (Figures 15, 16, 17). A front or even successive fronts of high pressure are propagating in the underground hitting the Quaternary layering composed of a sandy-gravelly aquifer below an impermeable cap of a nagelfluh plate and additional few meters of clay and loam (Figure 15). Despite its strong cementation, the nagelfluh plate is assumed to have a few weak points. Today, the ground-water level in the Thunderhole region is just above $30 \mathrm{~m}$, but in the Kienberg region perched water aquifers are widely known to exist in the upper 10-15 m. This scenario is assumed also for the time of the impact as shown in Figure 15, although liquefaction at $30 \mathrm{~m}$ depth has also been reported for earthquakes $[3,25]$. Here it is suggested that the local concentration of the Thunderholes may also be related to this special geologic-hydrogeological setting of a near-surface confined aquifer. In the second stage of Thunderhole formation (Figure 16) high pressure is transferred to the confined aquifer resulting in rock liquefaction, relieving high pressure upwards at weak points of the nagelfluh bed and injecting fluidized sandy-gravelly material into the clayey-loamy cap rock, which becomes widely bulged. Moreover, the injection from below must have been extremely powerful so as to transport blocks of nagelfluh weighing several $100 \mathrm{~kg}$ more than one meter upwards as seen in the Thunderhole \#2 excavation. Partly, the injections obviously could penetrate the cap rock to form extrusions as suggested by the geophysical measurements at the Mörn farmhouse (Figure 12). Clear extrusion evidence is also given by nagelfluh and gravel found scattered around the excavation pit of Thunderhole \#2 otherwise not to be expected on top of the loess surficial layer.

Except for the acute collapse, the third stage of Thunderhole formation is a slow process that proceeds in the 2,500-4,000 years following the impact and shock wave propagation and is still ongoing (Figure 17). Through seismic shaking and the water-rich sandygravelly-nagelfluh intrusions, as well as their mixing with the cap rock and possibly with degassing groundwater (resulting in arching layers), the underground must have become strongly broken up and instable like a strongly 


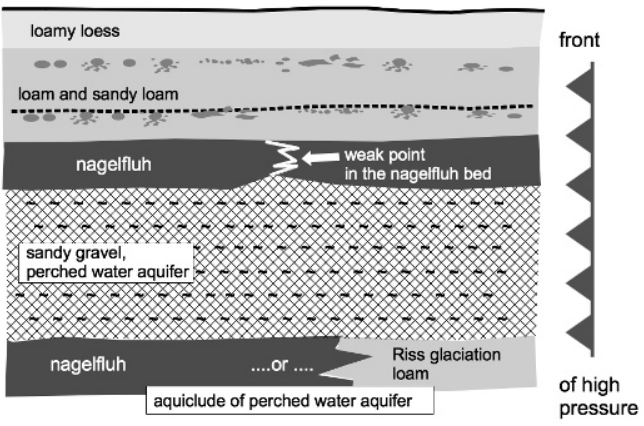

Figure 15. First stage of Thunderhole formation: approaching fronts of shock pressure and seismic waves.

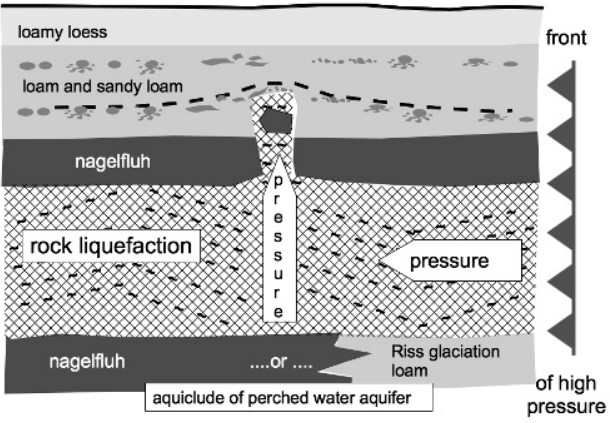

Figure 16. Second stage of Thunderhole formation: rock liquefaction, nagelfluh perforation and highly energetic mass transport upwards.

ploughed soil. This enabled a more or less continuous washout of the fine-grained component over months and thousands of years leading to open cavities in the subsurface as seen in Figure 8, and, in the end, led to a collapse which formed the sudden surficial Thunderhole cave-ins. In the regions of the New Madrid earthquake (200 years ago) soil liquefactions, farmers, even today, are warned to drive their heavy agricultural machines across the extrusive sand boils, and vehicles have been reported to have completely caved in $[3,25]$ - like with the Chiemgau Thunderholes. It may be argued that a time span of about 200 years may reasonably apply to a process of underground instability like in the case of the New Madrid earthquake but it is hardly understandable how the proposed impact has continued to have an effect over thousands of years. Therefore we emphasize that the impact shock-induced disequilibrium lasted only a very short time of the order

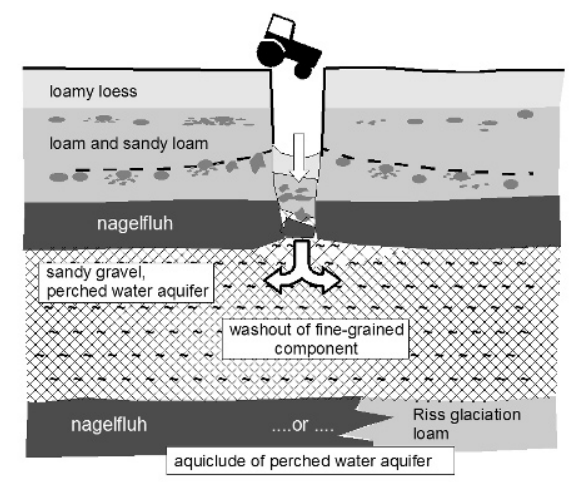

Figure 17. Third stage of Thunderhole formation: Long-lasting washout of the fine-grained component over months and thousands of years leads to underground cavity development and final collapse as has now been excavated (compare Figure 6).

of seconds and minutes and that a geologic equilibrium should have arrived shortly afterwards. In this respect the Thunderhole formation does not deviate from other processes like long-lasting carbonate dissolution or longlasting internal erosion to produce sinkholes.

\section{Conclusions}

Among the various possibilities of sinkhole formation known from all over the world including karst dissolution, tectonic and earthquake processes, gas activities, strong water table oscillations, piping, mining damage, etc., the Kienberg Thunderhole occurrence stands out, which is underlined by the "enigmatic" designation within living memory, even for geologists. Excavations and geophysical measurements have revealed liquefaction to be the most probable process to explain the observations. Rock or soil liquefaction is a well-known and fairly well understood process that is observed during strong earthquakes but also has been assessed to paleoseismicity (e.g., [4, 22, 4548]). It is not surprising that from the viewpoint of meteorite impact research, paleo-liquefaction features in older sediments may be attributed to seismic shaking induced by large impacts, although, of course, strong earthquakes have always been much more frequent than large impacts. So far known there is only one case where synsedimentary deformation has been discussed to have possibly originated from impact shaking; a relation is established to the $6 \mathrm{~km}$-diameter Upheaval Dome impact structure in southeastern Utah, USA [16]. Because of the relatively small impact structure and the pipe-like liquefaction features 
occurring at great distance of about $260 \mathrm{~km}$, the association of the liquefaction with the Upheaval Dome impact has been questioned [49].

The proposed Chiemgau impact event is different. The observation of the typical liquefaction features probably related directly with a large impact event only 2,500-4,000 years ago and, excluding practically any other process of formation, has geologic and geophysical significance. The idea entertained by Alvarez et al. [16] that paleoliquefaction features need not necessarily originate from paleoseismicity has been substantiated by the investigation of the Chiemgau impact Thunderhole phenomenon, and the peculiar features and processes occurring here add to the important conception of impact cratering as a geologic process [50]. Hence, and following the idea of Alvarez et al., it may be interesting to investigate whether fossil "Thunderholes" can be observed in sediments as companions to impact structures more frequently. So far no other sites of liquefaction especially linked to young impacts have been described which might be explained by their occurrence on hard rock targets or in remote regions not well investigated geologically.

A question remains unanswered for the time being. From earthquakes it is known that liquefaction explosion can produce perfectly circular craters $[3,9]$ that sometimes are reminiscent of smaller craters in the Chiemgau impact strewn field. While in the Chiemgau area many craters show clear impact signature like melt rocks, shock effects and distinct geomagnetic anomalies [36, 51-53] others do not. Hence, the possibility that both meteorite impact and liquefaction craters may exist in and contribute to the crater-strewn field may not completely be excluded and has yet to be verified.

\section{Acknowledgements}

For manifold support we thank T. Ernstson, F. Huber, J. Lex, M. Maier, H.-P. Matheisl, E. Neugebauer, B. Rappenglück, H. Schiebl, J.F. Townsend and H. Urbauer, as well as four anonymous reviewers.

\section{References}

[1] Doppler G., Geological map of Bavaria (1: 25,000), sheet \#7941 Trostberg, 1982

[2] Bayerisches Geologisches Landesamt (ed.), Geological map of Bavaria, (1: 500,000), 4th edition, 1997

[3] Stewart D., Knox R., The earthquake that never went away. Gutenberg-Richter Publications, Marble Hill, MO, 1993
[4] Sims J.D., Garvin C.D., Recurrent liquefaction at Soda Lake, California, induced by the 1989 Loma Prieta earthquake, and 1990 and 1991 aftershocks: Implications for paleoseismicity studies. B. Seismol. Soc. Am., 1995, 85, 51-65

[5] Obermeier S.F., The New Madrid Earthquakes: An engineering-geologic interpretation of relict liquefaction features. U.S. GPO, Washington, 1989

[6] Obermeier S.F., Liquefaction evidence for strong earthquakes of Holocene and Latest Pleistocene ages in the states of Indiana and Illinois, USA. Eng. Geol., 1998, 50, 227-254

[7] Tuttle M.P., Hengesh J., Tucker K.B., Lettis W., Deaton S.L., Frost J.D., Observations and comparisons of liquefaction features and related effects induced by the Bhuj earthquake. Earthq. Spectra, 2002, 18 (Supp. A), 79-100

[8] Youd T.L., Liquefaction mechanisms and induced ground failure. In: Lee W.H.K., Kanamori H., Jennings P.C., Kisslinger C. (Eds.), International Handbook of Earthquake and Engineering Seismology, Part B, Amsterdam, Academic Press, 2003, 1159-1173

[9] Rydelek P.A., Tuttle M., Seismology: Explosive craters and soil liquefaction. Nature, 2004, 427, 115116

[10] González de Vallejo L.I., Tsigé M., Cabrera L., Paleoliquefaction features on Tenerife (Canary Islands) in Holocene sand deposits. Eng. Geol., 2005, 76, 179190

[11] Wang C.-Y., Wong A., Dreger D.S., Manga, M., Liquefaction limit during earthquakes and underground explosions: implications on groundmotion attenuation. B. Seismol. Soc. Am., 2006, 96, 1, 355-363

[12] Obermeier S.F., Pond E.C., Olson S.M., Green R.A., 2002, Paleoliquefaction studies in continental settings. In: Ettensohn F.R., Rast N., Brett C:E., Ancient seismites. The Geological Society of America, Boulder, CO, 2002, 13-27

[13] Huuse M., Jackson C.A.-L., Rensbergen P.v., Davies R.J., Flemings P.B., Dixon R.J., Subsurface sediment remobilization and fluid flow in sedimentary basins: an overview. Basin Research, 2010, 22, 4, 342-360, URL: http: //onlinelibrary.wiley.com/doi/10 . 1111/j.1365-2117.2010.00488.x/full

[14] Hurst A., Scott A., Vigorito M., Physical characteristics of sand injectites. Earth Sci. Rev., 2011, 106, 3-4, 215-246, URL: http://www.sciencedirect. com/science/article/pii/S0012825211000250

[15] Ross J.A., Peakall J., Keevil G.M., An integrated model of extrusive sand injectites in cohesionless sediments. Sedimentology, 2011, URL: http://onlinelibrary.wiley.com/doi/10. 
$1111 / j .1365-3091.2011 .01230 . x /$ abstract

[16] Alvarez W., Staley E., O'Connor D., Chan M.A., Synsedimentary deformation in the Jurassic of southeastern Utah, a case of impact shaking? Geology, 1998, 26, 579-582

[17] Richardson J.E., Melosh H.J., Greenberg R.J., O'Brien D.P., The global effects of impact-induced seismic activity on fractured asteroid surface morphology. Icarus, 2005, 179, 325-349

[18] Kirsch R. (Ed.), 2006, Groundwater Geophysics: A tool for Hydrogeology. Springer, Berlin, 2006

[19] Wolf L.W., Collier J., Tuttle M., Bodin P., Geophysical reconnaissance of earthquake-induced liqefaction features in the New Madrid seismic zone. J. Appl. Geophys., 1998, 39, 121-129

[20] Wolf L.W., Tuttle M.P., Browning S., Park S., Geophysical surveys of earthquake-induced liquefaction deposits in the New Madrid seismic zone. Geophysics, 2006, 71, B223-230

[21] Al-Shukri H., Mahdi H.H., Tuttle M., Threedimensional imaging of earthquake-induced liquefaction features with ground penetrating radar near Marianna, Arkansas. Seismol. Res. Lett., 2006, 77, 505513

[22] Obermeier S.F., Using liquefaction-induced features for paleoseismic analysis. In: McCalpin J.P. (Ed.), Paleoseismology. Academic Press, San Diego, CA, 1996, 331-396

[23] Johnston A.C., Schweig E.S., The enigma of the New Madrid Earthquakes of 1811-1812. Annu. Rev. Earth. Pl. Sc., 1996, 24, 339-384

[24] Tuttle M., Barstow N., Liquefaction-Related Ground Failure: A Case Study in the New Madrid Seismic Zone, Central United States. B. Seismol. Soc. Am., 1996, 86, 636-645

[25] Stewart D., Knox R., 1995, The earthquake America forgot. Gutenberg-Richter Publications, Marble Hill, MO, 1995

[26] Knox R., Stewart D., The New Madrid fault finders guide. Gutenberg-Richter Publications, Marble Hill, MO, 1995

[27] Grünthal G., Mayer-Rosa D., Lenhardt W., Abschätzung der Erdbebengefährdung für die D-A-CHStaaten -Deutschland, Österreich, Schweiz [Estimate of earthquake hazard for the D-A-CH countries Germany, Austria, Switzerland]. Bautechnik, 1998, 75, $753-767$ (in German)

[28] Galli P., New empirical relationhips between magnitude and distance for liquefaction. Tectonophysics, 2000, 324, 3, 169-187

[29] Higgins C.G., Schoner C., Sinkholes formed by piping into buried channels. Geomorphology,1997,20,307312
[30] Ormö J., Rossi A.P., Komatsu G., The Sirente crater field, Italy, Meteorit. Planet. Sci., 2002, 37, 15071523

[31] Stoppa F., The Sirente crater, Italy: Impact versus mud volcano origins, Meteorit. Planet. Sci., 2006, 41, 467-477

[32] Speranza F., Sagnotti L. Rochette P., An anthropogenic origin of the "Sirente crater", Abruzzi, Italy. Meteorit. Planet. Sci., 2004, 39, 635-649

[33] Ormö J., Koeberl C., Rossi A.P., Komatsu G., Geological and geochemical data from the proposed Sirente crater field: New age dating and evidence for heating of target, Meteorit. Planet. Sci., 2006, 41, 1331-1345

[34] Speranza F., Nicolosi I., Ricchetti N., Etiope G., Rochette P., Sagnotti L., DeRitis R., Chiappini M., The "Sirente crater field," Italy, revisited. J. Geophys. Res., 2009, 114, B03103, doi:10.1029/2008JB005759

[35] Schüssler U., Rappenglück M., Ernstson K., Mayer W., Rappenglück, B., Das Impakt-Kraterstreufeld im Chiemgau [The impact crater strewn field in the Chiemgau region]. Eur. J. Mineral. 2005, 17, Beihefte 1, 124 (in German)

[36] Ernstson K., Mayer W., Neumair A., Rappenglück B., Rappenglück M.A., Sudhaus D., Zeller K.W., The Chiemgau Crater Strewn Field: Evidence of a Holocene Large Impact Event in Southeast Bavaria, Germany. Journal of Siberian Federal University, Engineering \& Technologies, 2010, 3, 1, 72103, URL: http://elib.sfu-kras.ru/bitstream/ 2311/1631/1/04_.pdf

[37] Rappenglück B., Rappenglück M.A., Ernstson K., Mayer W., Neumair A., Sudhaus D., Liritzis I., The fall of Phaethon. A Greco-Roman geomyth preserves the memory of a meteorite impact in Bavaria (south-east Germany). Antiquity, 2010, 84, 428-439, URL: http: //antiquity .ac.uk/ant/084/ant0840428.htm

[38] Liritzis I., Zacharias N., Polymeris G.S., Kitis G., Ernstson K., Sudhaus D., Neumair, A., Mayer W., Rappenglück M.A., Rappenglück B., The Chiemgau meteorite impact and tsunami event (Southeast Germany): First OSL dating. Mediterr. Archaeol. Ar., 2011, 10, 17-33 (in press)

[39] Hiltl M., Bauer F., Ernstson K., Mayer W., Neumair A., Rappenglück M.A., SEM and TEM analyses of minerals xifengite, gupeiite, Fe2Si (hapkeite?), titanium carbide ( $\mathrm{TiC}$ ) and cubic moissanite $(\mathrm{SiC})$ from the subsoil in the Alpine Foreland: Are they cosmochemical? 42nd Lunar and Planetary Science Conference, 2011, Abstract 1391.pdf., URL: http://www.lpi.usra.edu/ meetings/1psc2011/pdf/1391.pdf

[40] Rappenglück B., Ernstson K., Mayer W., Neumair A., 
Rappenglück M.A., Sudhaus D., Zeller K.W., The Chiemgau impact: an extraordinary case study for the question of Holocene meteorite impacts and their cultural implications. In: Rubiño-Martín J.A., Belmonte J.A., Prada F., Alberdi A. (Eds.), Cosmology across cultures. Proceedings of a workshop held at Parques de las Ciencias, Granada, Spain, 8-12 September 2008. Astronomical Society of the Pacific, San Francisco, 2009, 338343, URL: http://www . aspbooks .org/a/volumes / article_details/?paper_id=30130

[41] Yang Z.Q., Verbeeck J., Schryvers D., Tarcea N., Popp J., Rösler W., TEM and Raman characterisation of diamond micro- and nanostructures in carbon spherules from upper soils. Diam. Relat. Mater., 2008, 17, $937-$ 943

[42] Rösler W., Hoffmann V., Raeymaekers B., Schryvers D., Popp J., Diamonds in carbon spherules - evidence for a cosmic impact? Meteorit. Planet. Sci., 2005, 40, Supplement (Proceedings of 68th Annual Meeting of the Meteoritical Society, held September 12-16, 2005 in Gatlinburg, Tennessee), 5114

[43] Collins G.S., Melosh H.J., Marcus R.A., Earth Impact Effects Program: A Web- based computer program for calculating the regional environmental consequences of a meteoroid impact on Earth. Meteorit. Planet. Sci., 2005, 40, 6, 817-840

[44] Rubtsov V., The Tunguska Mystery. Springer, Berlin, 2009

[45] Amick D., Maurath G., Gelinas R., Characteristics of seismically induced liquefaction sites and features located in the vicinity of the 1886 Charleston, South Carolina, earthquake. Seismol. Res. Lett., 1990, 61, $2,117-118$
[46] Munson P.J., Munson C.A., Pond, E.C., Paleoliquefaction evidence for a strong Holocene earthquake in south-central Indiana. Geology, 1995, 23, 325-328

[47] Tuttle M.P., Schweig E.S., Recognizing and dating prehistoric liquefaction features: Lessons learned in the New Madrid seismic zone, central United States. Journal of Geophys. Res., 1996, 101, B3, 6171-6178

[48] Tuttle M.P., The use of liquefaction features in paleoseismology: Lessons learned in the New Madrid seismic zone, central United States. J. Seismol., 2001, 5, 361-380

[49] Huntoon P.W., Upheaval Dome, Canyonlands, Utah: Strain indicators that reveal an impact origin. In: Sprinkel D.A., Chidsey Jr. T.C., Anderson P.B. (Eds.), Geology of Utah's Parks and Monuments. Utah Geological Association, Salt Lake City, 2000, 1-10

[50] Melosh H.J., Impact cratering: A geologic process. Oxford University Press, New York, 1989

[51] Fehr K.T., Pohl J., Hochleitner R., Burghausen meteorite strewn field: Status report, August 2002 (in German)

[52] Hoffmann V., Rösler W., Patzelt A., Raeymaekers B., Van Espen P., Characterisation of a small crater-like structure in SE Bavaria, Germany. Meteorit. Planet. Sci., 2005, 40, Supplement (Proceedings of 68th Annual Meeting of the Meteoritical Society, September 12-16, 2005 in Gatlinburg, Tennessee), 5158

[53] Rösler W., Patzelt A., Hoffmann V., Raeymaekers B., Characterisation of a small crater-like structure in SE Bavaria, Germany: Abstract, European Space Agency, First International Conference on Impact Cratering in the Solar System, ESTEC, Noordwijk, The Netherlands, 08 - 12 May., 2006 